RICYDE. Revista Internacional de Ciencias del Deporte doi: $10.5232 /$ ricyde

Rev. int. cienc. deporte

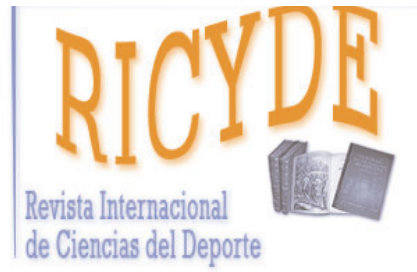

RICYDE. Revista Internacional de Ciencias del Deporte VOLUME XII - YEAR XII

Pages:79-89 ISSN:1885-3137

Issue 43 - January - 2016

\title{
The effects of autonomy support in physical education classes Efectos del soporte de autonomía en clases de educación física
}

\author{
Juan Antonio Moreno-Murcia \& Francisco Sánchez-Latorre \\ Universidad Miguel Hernández de Elche. Spain
}

\begin{abstract}
The aim of this study was to analyze the behavioral, affective and cognitive effects that an intervention based on autonomy support has in physical education classes. The sample consisted of 145 students aged between 10 and $12(M=10.37 ; S D=.68)$. The experimental group $(n=91)$ consisted of four groups (two fifth grade and two sixth) and control group $(n=54)$ for a fifth year and one sixth of primary education. Autonomy support, the basic psychological needs, intrinsic motivation, importance attributed to physical education and the rate of regular physical activity were measured. Before the study began, the instructor involved participated in a workshop on autonomy support. During the same he was taught the concepts advocated by the SDT motivation and behavior training to facilitate greater levels of autonomy support, in addition to lowering the driver style statements in their classes. After the intervention (21 programmed physical education classes in four months), the results showed that the experimental group experienced significant increases in autonomy, intrinsic motivation, importance of physical education, intention to do sport and regular physical activity. Autonomy support in students had positive cognitive, affective and behavioral consequences.
\end{abstract}

Key words: self-determination theory; intervention; motivation, adherence; physical exercise.

\section{Resumen}

El objetivo de este estudio fue analizar los efectos comportamentales, afectivos y cognitivos de una intervención basada en el soporte de autonomía en clases de educación física. La muestra estuvo compuesta por 145 estudiantes con edades comprendidas entre los 10 y 12 años $(M=10.37 ; S D=.68)$. El grupo experimental ( $n=91$ ) estuvo compuesto por cuatro grupos (dos de quinto curso y dos de sexto) y el grupo control $(n=54)$ por un curso de quinto y otro de sexto de educación primaria. Se midió el soporte de autonomía, las necesidades psicológicas básicas, la motivación intrínseca, la importancia atribuida a la educación física, la intención de práctica de actividad física y tasa de actividad física habitual. Antes de que el studio empezara, se llevó a cabo un seminario de soporte de autonomía con el docente. Durante el mismo se le enseñó los conceptos de motivación propugnados por la SDT y los comportamientos de formación para facilitar mayores niveles de apoyo a la autonomía, además de bajar las declaraciones de estilo controlador en sus clases. Tras la intervención ( 21 clases de educación física programadas en cuatro meses), los resultados mostraron incrementos significativos en el grupo experimental en autonomía, motivación intrínseca, importancia a la educación física, intención de práctica y actividad física habitual. El soporte de autonomía en los estudiantes tuvo consecuencias positivas cognitivas, afectivas y comportamentales.

Palabras clave: teoría de autodeterminación; intervención; motivación, adherencia; ejercicio físico. 


\title{
The effects of autonomy support in physical education classes
}

\begin{abstract}
A high percentage of children and adolescents do not meet the recommendations of regular physical activity (Trost \& Loprinzi, 2008), and many of them do not do extracurricular physical activity (Centers for Disease Control and Prevention CDC, 2010). This is occurring in spite of the fact that physical activity is seen to be an important prevention tool, which is made evident from the high number of research papers highlighting the benefits it provides people (Capdevila, 2005; Casimiro, 2001; Carranza \& Mora, 2003; Nieman, 1999). In addition, several studies highlight the dangers that a lack or absence of exercise can imply for physical, mental and social health (Gray \& Leyland, 2008; Mathers, Vos, \& Stevenson, 2000; Eisenmann, 2004). These circumstances explain why encouraging active and healthy life styles is becoming an educational and health priority in different countries (European Union Working Group, Sport and Health, 2008), and as such, there is a clear need to continue advancing in the study of teaching strategies that lead to more active and healthier life styles.
\end{abstract}

According to Ryan \& Deci $(2000,2002)$, in their interaction with the environment, people can regulate their behavior autonomously and willingly, thereby favoring the quality of their involvement and psychological well-being. However, if to the contrary, the social environment acts in a controlling way, this innate tendency will become frustrated and produce uneasiness. In this sense, some studies (Ntoumanis \& Standage, 2009; Standage \& Gillison, 2007) show that a climate of autonomy support positively predicts the basic psychological needs, self-determined motivation and various positive consequences. An example of this is the use of democratic teaching styles (Tomasetto, 2004), fostering the importance of learning and progress above the task through the promotion of task-involved motivational climates (Barkoukis, Tsorbatzoudis, \& Grouios, 2008) and autonomy support (Reeve 2002; Julian, 2012; Moreno-Murcia, Conde, \& Sáenz-López, 2012). In general, support provided by teachers in the classroom has direct effects on students' emotional and motivational responses inside and outside the classroom (Moreno-Murcia, Huéscar, \& Cervelló, 2012; Ntoumanis \& Standage, 2009). Similarly, these types of strategies have been observed to foster the desired outcomes beyond the classroom, such as participation in extracurricular activities (Hagger et al., 2003; Tomasetto, 2004).

Physical education can be an ideal environment for acquiring knowledge and developing the attitudes and competences necessary for integrating physical exercise in life. The purpose of this study was to examine the influence of a motivational theory of Self-Determination (Autonomy support) based intervention on behaviors of adolescent students. Therefore, the aim of this intervention was to analyze the effect that autonomy support had on the basic psychological needs, intrinsic motivation, the importance attributed to physical education, intention to do physical education and the rate of physical exercise in school children during physical education classes. After the intervention, in comparison with the participants from the control group, the students from the experimental group were expected to improve in the basic psychological needs, intrinsic motivation, the importance attributed to physical education, future intention to participate in physical activities and rate of exercises. 


\section{Method}

\section{Participants}

The sample was selected intentionally and consisted of 145 students ( 71 boys and 74 girls) aged between 10 and $12(M=10.73 ; S D=.62)$, in the fifth and sixth year of primary education at two Spanish schools. The sample was divided into an experimental group (four groups, two fith and two sixth) of 91 students (51 boys and 40 girls) and a control group (two groups, one fith and one sixth) of 54 students (20 boys and 34 girls). All participants are enrolled in the educational system, so they had all received physical education classes throughout their schooling.

\section{Measures}

Teacher's care. We used the shortened version of the Teacher's Care scale by Saldern and Littig (1987), validated to the Spanish context by Moreno-Murcia, Ruiz, and Silveira (in print), which measures how teachers concern themselves with their students. It was preceded by "Our teachers..." and consists of four items (e.g. "They deal with students' problems". Responses are given on a Likert scale from 1 (That's never true for me) to 4 (That is often true for me). Cronbach's alpha was .70 in the pretest and .68 in the post-test.

Perception of autonomy support in class. This was measured using the Student's Perception of Autonomy Support by Röder and Kleines (2007) validated to the Spanish context by Ruiz (2015). This scale is preceded by the heading "In class we can often decide...", and consists of five items (e.g. "whether we want to work alone or in a group" answered on a Likert scale from (That's never true for me) to 4 (That's often true for me). Internal consistency was .77 in both the pretest and the post-test.

Psychological mediators. The Psychological Need Satisfaction in Exercise Scale (PNSES) by Wilson et al. (2006), validated to the Spanish context by Moreno-Murcia, Marzo, MartínezGalindo, and Conte (2011) was used to measure the basic psychological needs. It has 18 items, with six items to evaluate each of the basic needs: competence (e.g. "I am confident enough to do the most challenging exercises"), autonomy (e.g. "I believe I can make decisions regarding my classes"), and relatedness (e.g. "I feel close to my classmates because they accept me as I am"). The introductory phrase was: "In my physical education classes ..." and the responses were given on a Likert scale ranging from 1 (False) to 6 (True). Cronbach's alpha was .85 in the pretest and .87 in the post-test.

Motivation. We used the intrinsic motivation (IM) factor from the Spanish version (Moreno Murcia, González-Cutre, \& Chillón, 2009) of the Perceived Locus of Causality Scale (PLOC) (Goudas et al., 1994). This factor opens with the phrase "I participate in this physical education class...", and consists of four items (e.g. "Because I enjoy learning new skills") which are answered on a Likert scale from 1 (I totally disagree) to 7 (I totally agree). Cronbach's values were .68 in the pretest and .83 in the post-test.

Importance and usefulness of physical education. The importance of physical education scale (IPE) by Moreno, Llamas, and Ruiz, (2006) was used. This questionnaire consists of three items: (e.g. "I consider it important to receive physical education classes"). Students respond on a Likert scale from 1 to 4 , where 1 corresponds to "Totally disagree" and 4 "Totally agree". Internal consistency was .72 in the pretest and .78 in the post-test. 
Intention to do physical activity. We used the adapted version of Intention to be Physically Active Scale (IPAS) (Hein et al., 2004) translated into Spanish by Moreno, Moreno, and Cervelló (2007). It consists of five items for measuring participants' intention to be physically active after leaving school (e.g. "Outside physical education classes, I like doing sport"). The items are preceded by the phrase "With respect to your intention to do a physical activity..." Responses correspond to a Likert scale ranging from 1 to 5, where 1 corresponds to "Totally disagree" and 5 to "Totally agree". Cronbach's alpha was .67 in the pre-test and .76 in the post-test.

Regular physical activity (RPA). We used the Spanish version (Sarria et al., 1987) of the Regular Physical Activity Questionnaire by Baecke, Burema, and Frijters (1982). Three scores for regular physical activity can be obtained through eight items related to physical exercises in leisure time (PEL) and leisure and locomotion activities (LLA). The sum of both gives the total score for regular physical activity. Calculation of the PEL score is based on four questions. The first question refers to the type of sport or sports, frequency per week, and months per year it is played. The score for this first question is calculated by applying the following formula: Mode $1=$ (Intensity x Proportion $\mathrm{x}$ Time) + Mode $2=$ (Intensity $\mathrm{x}$ Proportion $\mathrm{x}$ Time). This formula, based on the intensity of physical activity expressed in hours a week and months a year, is calculated by assigning a series of coefficients (see Ainsworth et al., 2000; Florindo \& Latorre, 2003). The other three questions evaluated the level of exercise during leisure time (e.g. "during my leisure time I do sport or physical exercise") on a Likert scale from 1 (Never) to 5 (Very often). To calculate the total PEL score, the result from the first question was converted into values from 1 to 5 and the average of the four questions was calculated. To obtain the LLA score, the averages of the four questions evaluating the level of physical activity during free time and locomotion (for example, during my leisure time I walk) were calculated using a Likert scale from 1 (Never) to 5 (Very often). Internal consistency was .71 in the pretest and .73 in the post-test.

Some dimensions presented a low internal consistency, which can be justified by the low number of items of the factors (Hair, Anderson, Tatham, \& Black, 1998).

\section{Research design and procedure}

As the groups involved were established classes, randomization could not be respected, so a quasi-experimental design for a nonequivalent control group was made (Campbell \& Stanley, 1966). The heads of both schools were contacted to inform them about the purpose of the research, the procedures and to ask for their consent. At the same time, the school board was informed, parents were asked for permission and the lead researcher met up with the teachers involved.

The pretest was administered first, and the post-test was given after the intervention. Both were completed in the corresponding school in presence of the teacher. Any term students were confused about was clarified, and they were encouraged to answer the questionnaires as sincerely as possible, stressing the anonymity of their responses. Completion of the questionnaire was carried out autonomously and in a calm and quiet atmosphere. The approximate time for completing the questionnaires was 25 minutes depending on the number of students and the agility of the class.

The intervention took place during 21 programmed physical education classes held twice a week, and included in the teaching program for February and May. Both the control group and the experimental group pursued the same academic competences in their respective didactic programs corresponding to the fifth and sixth year of primary school. 
Teacher instruction. He recruited a professor of physical education for this study. The purpose of using a teacher was because (a) the consistency of teaching style beyond the elements manipulated in the study and (b) designing a program to perform for three months. Before the study began, the instructor involved participated in a individual workshop on autonomy support. During this workshop (twelve hours), you will be taught the concepts of motivation espoused by the SDT (Deci \& Ryan, 2002) and behaviors for training to facilitate greater levels of support to autonomy, while lower their statements driver style in your workouts (Reeve et al., 2004; Pelrman, 2015; Perlman \& Webster, 2011). During the workshop, fragments of classes where the teacher instructed using the autonomy support, seeking to develop their own behaviors instruction through teaching lessons were college students. Once the teacher completed the workshop, measurements were carried out in a pilot study of four classes with students who were not involved with the study. The purpose of the implementation of this pilot study was to ensure and assist teachers in the implementation of each approach (support for autonomy and control) properly, and thus get a intraobserver reliability of at least $90 \%$.

Unlike the control group, the experimental group received an intervention methodology which sought to give students autonomy support (Reeve, 2009). The teacher of this group was trained to suitably transmit a climate of autonomy support, characterized by: using informal, flexible and non-controlling language; permitting criticism and encouraging independent thought; reasoning with students about respect for and the value of the feelings, thoughts and behaviors of others, being open to modifying demands and uninteresting activities and structures; adopting an "empathetic" listening attitude; encouraging students' intrinsic motivational resources ("I want to do this"); providing challenges and options; taking their preferences and interests into account, and stimulating their curiosity; helping students understand how school work contributes to the achievement of personal goals; establishing interesting and relevant activities; giving students time to work independently and in their own way and allowing them to take the initiative in learning activities. Three sessions were recorded on video in each group to assess the support for the autonomy and frequency controller instruction. For the purpose of this study, the treatment group was required (a) verify a significant change in the perception of autonomy support and (b) provide a minimum of $80 \%$ of the information to support autonomy (Perlman, 2015). Furthermore, in the control group it was checked whether the statements were balanced instrutor (ie, $40 \%$ support the autonomy and control of $60 \%$ ). The data obtained in the measurement of teaching scenarios indicated by Reeve and Jang (2006) were: experimental group ( $84 \%, 89 \%$ and $82 \%$ in support of autonomy) and control group ( $42 \%, 48 \%$ and $51 \%$ in controls).

\section{Data analysis}

To analyze whether there were any differences between the control group and the experimental group in the study's target variables before the intervention, a Levene test was made with the pretest variables of the groups. To answer the research questions, repeated measures ANOVAs were calculated (Dependent variable: basic psychological needs, intrinsic motivation, importance attributed to physical education, intention to do physical activity and rate of physical activity; Independent variable: control group and experimental group). Internal consistency of each factor was analyzed using Cronbach's alpha coefficient. The data were analyzed using the SPSS 21.0 statistics program. 


\section{Results}

No differences were observed between the experimental group and the control group before the intervention, except in intrinsic motivation $(p<.05)$ and in intention to do sport $(p<.05)$, both of which had a higher score in the experimental group.

To avoid any discrepancy between what we believed we were doing and what we were actually doing, autonomy support in the student was measured. By including this, we aimed to obtain perceptions on granting autonomy in the classroom, and thereby gather information about the effects that the pursuit for autonomy program had on students. After he conducted a repeated measure anova, we measured the effect of the intervention on the experimental group in teacher care $\left(M_{\text {Pre } 1}=3.13\right.$ y $\left.M_{\text {Post } 2}=3.29, p<.05\right)$ and perception of autonomy $\left(M_{\text {Pre } 1}=\right.$ 1.62 y $\left.M_{\text {Post } 2}=2.34, p<.01\right)$. While in the control group the following data were obtained: teacher care $\left(M_{\text {Pre } 1}=3.02\right.$ y $\left.M_{\text {Post } 2}=3.21, p>.05\right)$ and perception of autonomy $\left(M_{\text {Pre } 1}=\right.$ 1.62 y $\left.M_{\text {Post } 2}=1.70, p>.05\right)$.

After the intervention, the data analysis (Table 1) showed that the experimental group improved in autonomy $(p<.01)$, intrinsic motivation $(p<.01)$, importance given to physical education $(p<.01)$, intention to do sport $(p<.05)$ and regular physical activity $(p<.05)$. The control group, however, only improved in the autonomy mediator $(p<.05)$ and in intrinsic motiation $(p<.01)$.

Table 1. Repeated Measures ANOVAs

\begin{tabular}{|c|c|c|c|c|c|}
\hline & & \multicolumn{2}{|c|}{$\begin{array}{l}\text { Experimental group } \\
(n=91)\end{array}$} & \multicolumn{2}{|c|}{$\begin{array}{l}\text { Control group } \\
(n=54)\end{array}$} \\
\hline \multicolumn{2}{|l|}{ Variables } & $M$ & $S D$ & $M$ & $S D$ \\
\hline \multirow{2}{*}{ Autonomy (PNSES) } & Pre & 2.48 & .93 & 2.27 & 1.12 \\
\hline & Post & $3.13^{* *}$ & .98 & $2.57^{*}$ & 1.09 \\
\hline \multirow{2}{*}{ Competence (PNSES) } & Pre & 4.73 & .87 & 4.60 & 1.06 \\
\hline & Post & 4.87 & 1.11 & 4.70 & 1.17 \\
\hline \multirow{2}{*}{ Relationship (PNSES) } & Pre & 4.42 & 1.01 & 4.41 & 1.20 \\
\hline & Post & 4.56 & .91 & 4.37 & 1.24 \\
\hline \multirow{2}{*}{ Intrinsic motivation (IM) } & Pre & 5.18 & .60 & 4.76 & .90 \\
\hline & Post & $5.73^{* *}$ & 1.08 & $5.47 * *$ & 1.25 \\
\hline \multirow{2}{*}{$\begin{array}{l}\text { Physical education importance } \\
\text { (IPE) }\end{array}$} & Pre & 3.05 & .56 & 3.11 & .67 \\
\hline & Post & $3.26^{* *}$ & .47 & 2.94 & .68 \\
\hline \multirow{2}{*}{ Intent of future practice (IPAS) } & Pre & 4.06 & .77 & 3.77 & .80 \\
\hline & Post & $4.20^{*}$ & .81 & 3.86 & .81 \\
\hline \multirow{2}{*}{ Regular physical activity (RPA) } & Pre & 5.14 & 1.33 & 5.34 & 1.06 \\
\hline & Post & $5.56^{*}$ & 1.21 & 5.55 & 1.09 \\
\hline
\end{tabular}




\section{Discussion}

The aim of the study was to test the effect of autonomy support on the basic psychological needs, intrinsic motivation, importance attributed to physical education, intention to do physical activity and rate of physical activity in school children during physical education classes. After the intervention, the expected consequences of the effect of autonomy support were not confirmed in full.

Our study, as in the study by Aibar et al. (2015), indicates that a teacher intervention that gives autonomy support increases the importance that students attribute to physical education, the intention to do it and the rate of physical activity outside school. Other studies confirm these results, ascertaining that the strategies of autonomy support are translated into a perception of autonomy support in students (Ntoumanis, 2005; Standage, Duda, \& Ntoumanis, 2005). Cheon and Reeve (2013) affirm that teachers are an important element for generating positive consequences in their students, guaranteeing the perception of autonomy by the learners themselves (Stroet et al., 2013) above the autonomy support encouraged in the intervention.

The type of motivation that the physical education teacher has promoted has influenced how the students value the subject (Moreno-Murcia et al., 2013), and in this particular case about the benefits of doing regular physical education. This increase in students' perceived autonomy during classes not only generates in them a greater willingness to be physically active outside the school environment (Cheon et al., 2012), but it also increases the rate of regular exercise. In which case, satisfying the basic psychological needs can lead to greater intrinsic motivation, greater intention to continue doing sport and a significant increase in the level of physical activity (Ickes, Erwin, \& Beighle, 2012; Moreno \& Huéscar, 2013; Verstraete, Cardon, De Clercq, \& De Bourdeaudhuij, 2006; Salmon, Booth, Phongsavan, Murphy, \& Timperio, 2007).

Some of the limitations of this study can be found in the actual characteristics of the participating population, lack of familiarity with completing questionnaires, the countless factors that influence the development of the programs during the course, or the complexity that is entailed in having an overall control of the strategies that we pursue in the intervention. In this case, other environments (social and family), which can influence the cognitive, affective and behavioral changes of students, have not been controlled. Further studies can broaden the results obtained by increasing the duration of the intervention, making direct measures of physical activity and testing retention, which would confirm the results over time. As already indicated by Reeve (2002), it would also be interesting to finally confirm in the learning context whether teacher autonomy support and its more instructional aspect can complement each other.

In conclusion, when the teacher provides physical education students with higher levels of autonomy in their pre-adolescent stage, they perceive themselves as more autonomous, and consequently their levels of intrinsic motivation towards the subject increase as does the importance that they attribute to it. This can improve the intention to be physically active outside the school environment, and therefore increase their commitment to sport. 


\section{References}

Aibar Solana, A.; Estrada Tenorio, S.; Murillo Pardo, B.; Bois, J.; Clemente, J.; Antonio, J., y García González, L. (2015). Actividad física y apoyo de la autonomía. Revista de Psicología del Deporte, 24, 155-161.

http://dx.doi.org/10.1097/00005768-200009001-00009

Ainsworth, B. E.; Haskell, W. L.; Whitt, M. C.; Irwin, M. L.; Swartz, A. M.; Strath, S. J.; O'Brien, W. L.; Bassett, D. R.; Schmitz, K. H.; Emplaincourt, P. O., \& Jacobs, J. R. (2000). Compendium of physical activities: an update of activity codes and MET intensities. Medicine Science Sports Exercise, 32(9), 498-504.

Baecke J.; Burema J., \& Frijters J. (1982). A short questionnaire for the measurement of habitual physical activity in epidemiological studies. The American Journal of Clinical Nutrition, 36, 936-942.

Barkoukis, V.; Tsorbatzoudis, H., \& Grouios, G. (2008). Manipulation of motivational climate in physical education: effects of a seven-month intervention. European Physical Education Review, 14(3), 367-387.

http://dx.doi.org/10.1177/1356336X08095671

Campbell, D. T., \& Stanley, J. C. (1966). Experimental and quasi-experimental designs for research. New York: Rand McNally y Company.

Capdevila, LI. (2005). Actividad Física y Estilo de Vida Saludable. Girona: Documenta universitaria.

Carranza, M., \& Mora, J. (2003) Educación física y valores: educando en un mundo complejo. Barcelona: Grao.

Casimiro, A. J. (2001). El acondicionamiento físico como fuente de educación, salud y rendimiento. Almería: Universidad de Almería.

Centers for Disease Control and Prevention (CDC) (2010). The association between school based physical activity, including physical education, and academic performance. Atlanta, GA: US Department of Health and Human Services.

Cheon, S. H., \& Reeve, J. (2013). Do the benefits from autonomy-supportive PE teacher training programs endure? A one-year follow-up investigation. Psychology of Sport and Exercise, 14(4), 508-518.

http://dx.doi.org/10.1016/j.psychsport.2013.02.002

Cheon, S. H.; Reeve, J., \& Moon, I. S. (2012). Experimentally based, longitudinally designed, teacher-focused intervention to help physical education teachers be more autonomy supportive toward their students. Journal of Sport \& Exercise Psychology, 34(3), 365-396.

Deci, E. L., \& R. M. Ryan (2002). Handbook of Self-Determination Research. New York: The University of Rochester Press.

Eisenmann, J. C. (2004). Physical activity and cardiovascular disease risk factors in children and adolescents: an overview. Canadian Journal of Cardiology, 20, 295-301.

Florindo, A. A., \& Latorre, M. R. D. O. (2003). Validation and reliability of the Baecke questionnaire for the evaluation of habitual physical activity in adult men. Revista Brasileira de Medicina do Esporte, 9, 129-135.

http://dx.doi.org/10.1590/s1517-86922003000300002

Goudas, M.; Biddle, S., \& Fox, K. (1994). Perceived locus of causality, goal orientations, and perceived competence in school physical education classes.British Journal of Educational Psychology, 64(3), 453-463.

http://dx.doi.org/10.1111/j.2044-8279.1994.tb01116.x 
Gray, L., \& Leyland, A. H. (2008). Overweight status and psychological well-being in adolescent boys and girls: a multilevel analysis. European Journal of Public Health 18(6), 616-621.

http://dx.doi.org/10.1093/eurpub/ckn044

Grupo de trabajo de la Unión Europea "Deporte y Salud" (2008). Directrices de actividad física de la UE. Actuaciones recomendadas para apoyar la actividad física que promueve la salud. Madrid: Consejo Superior de Deportes.

Hagger, M. S.; Chatzisarantis, N. L.; Culverhouse, T., \& Biddle, S. J. (2003). The Processes by Which Perceived Autonomy Support in Physical Education Promotes Leisure-Time Physical Activity Intentions and Behavior: A Trans Contextual Model. Journal of Educational Psychology, 95, 784-795. http://dx.doi.org/10.1037/0022-0663.95.4.784

Hair, J. F.; Anderson, R. E.; Tatham, R. L., \& Black, W. C. (1998). Multivariate data analysis. Upper Saddle River, N. J: Prentice-Hall.

Hein, V.; Müür, M. \& Koka, A. (2004). Intention to be physically active after school graduation and its relationship to three types of intrinsic motivation. European Physical Education Review, 10(1), 5-19. http://dx.doi.org/10.1177/1356336X04040618

Ickes, M.; Erwin, H., \& Beighle, A. (2012). Systematic review of recess interventions to increase physical activity. Journal of Physical Activity and Health, 10(6), 910-26.

Julián, J. A. (2012). Motivación e intervención docente en la clase de educación física. Tándem. Didáctica de la Educación Física, 40, 7-17.

Mathers, C. D.; Vos, E. T.; Stevenson, C. E., \& Begg, S. J. (2000). The Australian Burden of Disease Study: measuring the loss of health from diseases, injuries and risk factors. Medical Journal of Australia, 172, 592-596.

Moreno, J. A.; González-Cutre, D., \& Chillón, M. (2009). Preliminary validation in Spanish of a scale designed to measure motivation in physical education classes: the Perceived Locus of Causality (PLOC) Scales. The Spanish Journal of Psychology, 12, 327-337. http://dx.doi.org/10.1017/S1138741600001724

Moreno, J. A.; Llamas, L. S., y Ruiz, L. M. (2006). Perfiles motivacionales y su relación con la importancia concedida a la Educación Física. Psicología Educativa, 12(1), 4963.

Moreno, J. A., Moreno, R., y Cervelló, E. (2007). El autoconcepto físico como predictor de la intención de ser físicamente activo. Psicología y Salud, 17(2), 261-267.

Moreno-Murcia J. A.; Zomeño T.; Marín L. M.; Ruiz L. M., y Cervelló E. (2013). Percepción de la utilidad e importancia de la educación física según la motivación generada por el docente. Revista de Educación, 362, 380-401.

Moreno-Murcia, J. A.; Conde, C., y Sáenz-López, P. (2012). Importancia del apoyo de autonomía en la figura del docente en educación física. Tándem. Didáctica de la Educación física, 40, 18-27.

Moreno-Murcia, J. A., \& Huéscar, E. (2013). The importance of supporting adolescents' autonomy in promoting physical-sport exercise. The Spanish Journal of Psychology, $16,81-98$. http://dx.doi.org/10.1017/sjp.2013.81

Moreno-Murcia, J. A.; Huéscar, E., \& Cervelló, E. (2012). Prediction of adolescents doing physical activity after completing secondary education. The Spanish Journal of Psychology, 15(1), 90-100.

http://dx.doi.org/10.5209/rev_SJOP.2012.v15.n1.37288 
Moreno-Murcia, J. A.; Marzo, J. C.; Martínez, C., y Conte, L. (2011). Validación de la Escala de "Satisfacción de las Necesidades Psicológicas Básicas" y del Cuestionario de la "Regulación Conductual en el Deporte" al contexto español. RICYDE. Revista Internacional de Ciencias del Deporte, 26(7), 355-369.

http://dx.doi.org/10.5232/ricyde2011.02602

Nieman, D. (1999). Exercício e Saúde. Sáo Paulo: Manole.

Ntoumanis, N. (2005). A prospective study of participation in optional school physical education using a self-determination theory framework. Journal of Educational Psychology, 97, 444-453.

http://dx.doi.org/10.1037/0022-0663.97.3.444

Ntoumanis, N., \& Standage, M. (2009). Motivation in physical education classes: a selfdetermination theory perspective. Theory and Research in Education, 7, 194-202. http://dx.doi.org/10.1177/1477878509104324

Perlman, D. J. (2015). Help motivate the amotivated by being a supportive teacher. Physical Education and Sport Pedagogy, 20(2), 204-214. http://dx.doi.org/10.1080/17408989.2013.868876

Perlman, D. J., \& C. A. Webster (2011). Supporting student autonomy in physical education. Journal of Physical Education, Recreation and Dance, 82(5), 46-49. http://dx.doi.org/10.1080/07303084.2011.10598628

Reeve, J. (2002). Self-determination theory applied to educational settings. En E. L. Deci, y R. M. Ryan (Eds.), Handbook of self-determination research, (pp. 183-203). Rochester, NY: University of Rochester Press.

Reeve, J. (2009). Why teachers adopt a controlling motivating style toward students and how they can become more autonomy supportive. Educational Psychologist, 44(3), $159-175$.

http://dx.doi.org/10.1080/00461520903028990

Reeve, J., \& Jang, H. (2006). What teachers say and do to support students' autonomy during a learning activity. Journal of Educational Psychology, 98, 209-218. http://dx.doi.org/10.1037/0022-0663.98.1.209

Reeve, J. H.; Jang, D.; Carrell, S.; Jeon, \& Barch, J. (2004). Enhancing students' engagement by increasing teachers' autonomy support. Motivation and Emotion, 28(2), 147-169.

http://dx.doi.org/10.1023/B:MOEM.0000032312.95499.6f

Röder, B., \& Kleine, D. (2007). Selbstbestimmung/Autonomie. En Skalendokumentation zum Forschungsprojekt "Selbstwirksamkeit und Selbstbestimmung im Unterricht". Extraido de: http://psilab.educat.huberlin. de/forschung/Skalenbuch_FoSS.pdf

Ruiz, M. (2015). Soporte de autonomía, motivación y educación. Consecuencias contextuales y globales. Elche: Universidad Miguel Hernández de Elche.

Ryan, R. M., \& Deci, E, L, (2002). An overview of self-determination theory: an organismic dialectic perspective. En E. L. Deci y R. M. Ryan (Eds.), Handbook of selfdetermination research (pp. 3-33). Rochester: The University of Rochester Press.

Ryan, R. M., \& Deci, E. L. (2000). Self-determination theory and the facilitation of intrinsic motivation, social development and well-being. American Psychologist, 55, 68-78. http://dx.doi.org/10.1037/0003-066X.55.1.68

Saldern, M. von, \& Littig, K. E. (1987). Landauer Skalen zum Sozialklima (LASSO 4-13). Weinheim: Beltz 
Salmon, J.; Booth, M. L.; Phongsavan, P.; Murphy, N., \& Timperio, A. (2007). Promoting physical activity participation among children and adolescents. Epidemiology Reviews, 29, 144-59.

http://dx.doi.org/10.1093/epirev/mxm010

Sarria, A.; Selles, H.; Cañedo-Arguelles, L.; Fleta, J.; Blasco, M. J., y Bueno, M. (1987). Un autotest como método de cuantificación de la actividad física en adolescentes. Nutrición Clínica y Dietética Hospitalaria, 7, 56-61.

Standage, M.; Duda, J. L., \& Ntoumanis, N. (2005). A test of self-determination theory in school physical education. British Journal of Educational Psychology, 75, 411-433. http://dx.doi.org/10.1348/000709904X22359

Standage, M., \& Gillison, F. (2007). Students' motivational responses toward school physical education and their relationship to general self-esteem and health-related quality of life. Psychology of Sport and Exercise, 8, 704-721. http://dx.doi.org/10.1016/j.psychsport.2006.12.004

Stroet, K.; Opdenakker, M. C., \& Minnaert, A. (2013). Effects of need supportive teaching on early adolescents' motivation and engagement: A review of the literature. Educational Research Review, 9, 65-87. http://dx.doi.org/10.1016/j.edurev.2012.11.003

Tomasetto, C. (2004). Influence style and students' orientation toward extracurricular activities: an application of the correspondence hypothesis. European Journal of Psychology of Education, 19(2), 133-145. http://dx.doi.org/10.1007/BF03173228

Trost, S. G., \& Loprinzi, P. D. (2008). Exercise-Promoting healthy lifestyles in children and adolescents. Journal of Clinical Lipidology, 2(3), 162-168. http://dx.doi.org/10.1016/j.jacl.2008.03.001

Verstraete, S. J.; Cardon, G. M.; De Clercq, D. L., \& De Bourdeaudhuij, I. M. M. (2006). Increas- ing children's physical activity levels during recess periods in elementary schools: the effects of providing game equipment. European Journal of Public Health $16,415-419$.

http://dx.doi.org/10.1093/eurpub/ckl008

Wilson, P. M.; Rodgers, W. M.; Loitz, C. C., \& Scime, G. (2006). "It's who I am ... really!" The importance of integrated regulation in exercise contexts. Journal of Applied Biobehavioral Research, 11, 79-104.

http://dx.doi.org/10.1111/j.1751-9861.2006.tb00021.x 